\title{
SEASONALITY OF NET RADIATION IN TWO SUB-BASINS OF PARACATU BY THE USE OF MODIS SENSOR PRODUCTS
}

\section{EVALDO DE P. LIMA ${ }^{1}$, GILBERTO C. SEDIYAMA ${ }^{2}$, BERNARDO B. DA SILVA ${ }^{3}$, JOSÉ M. GLERIANI ${ }^{4}$, VICENTE P. SOARES ${ }^{5}$}

\begin{abstract}
The net radiation $(\mathrm{Rn})$ represents the main source of energy for physical and chemical processes that occur in the surface-atmosphere interface, and it is used for air and soil heating, water transfer, in the form of vapor from the surface to the atmosphere, and for the metabolism of plants, especially photosynthesis. If there is no record of net radiation in certain areas, the use of information is important to help determine it. Among them we can highlight those provided by remote sensing. In this context, this work aims to estimate the net radiation, with the use of products of MODIS sensor, in the sub-basins of Entre Ribeiros creek and Preto River, located between the Brazilian states of Goiás and Minas Gerais. The SEBAL (Surface Energy Balance Algorithm for Land) was used to obtain the Rn in four different days in the period of July to October, 2007. The Rn results obtained were consistent with others cited in the literature and are important because the orbital information can help determine the $\mathrm{Rn}$ in areas where there are not automatic weather stations to record the net radiation.
\end{abstract}

KEYWORDS: meteorological information, river basins, remote sensing.

\section{SAZONALIDADE DO SALDO DE RADIAÇÃO EM DUAS SUB-BACIAS DO PARACATU POR MEIO DA UTILIZAÇÃO DE PRODUTOS DO SENSOR MODIS}

RESUMO: O saldo de radiação (Rn) representa a principal fonte de energia para os processos físico-químicos que ocorrem na interface superfície-atmosfera, sendo utilizado no aquecimento do ar e do solo, transferência da água, na forma de vapor da superfície para a atmosfera, e metabolismo das plantas, especialmente a fotossíntese. Se não houver o registro do saldo de radiação em determinadas áreas, torna-se importante a utilização de informações que ajudem a determiná-lo. Entre elas, podemos destacar as fornecidas por sensoriamento remoto. Neste contexto, este trabalho tem o objetivo de determinar o saldo de radiação, com a utilização de produtos do sensor MODIS, nas sub-bacias do Ribeirão Entre Ribeiros e Rio Preto, que ficam entre os Estados de Goiás e Minas Gerais. O SEBAL (Surface Energy Balance Algorithm for Land) foi utilizado para a obtenção do $\mathrm{Rn}$ em quatro dias diferentes, no período de julho a outubro de 2007. Os resultados encontrados foram compatíveis com outros citados em literatura e são importantes, pois as informações orbitais podem auxiliar na determinação do $\mathrm{Rn}$ em áreas onde não existam estações meteorológicas automáticas que registrem o saldo de radiação.

PALAVRAS-CHAVE: informação meteorológica, bacias hidrográficas, sensoriamento remoto.

\footnotetext{
${ }^{1}$ Meteorologista, Dr. Pesquisador, CNPS/EMBRAPA, Rua Jardim Botânico No 1024 - Jardim Botânico, Rio de Janeiro - RJ, evaldo.lima@embrapa.br.

${ }^{2}$ Eng $^{\circ}$ Agrônomo, Ph.D. Prof. Titular, Engenharia Agrícola, CCA/UFV, g.sediyama@ufv.br.

${ }^{3}$ Meteorologista, Dr. Prof. Visitante, Ciências Geográficas, CFCH/UFPE, bbdasilva.ufpe@gmail.com.

${ }^{4} \mathrm{Eng}^{\circ}$ Agrônomo, Dr. Prof. Adjunto, Engenharia Florestal, CCA/UFV, gleriani@gmail.com.

${ }^{5}$ Eng ${ }^{\circ}$ Florestal, Ph.D. Prof. Associado, Engenharia Florestal, CCA/UFV, vicente@ufv.br.

Recebido pelo Conselho Editorial em: 15-3-2011

Aprovado pelo Conselho Editorial em: 24-8-2012
} 


\section{INTRODUCTION}

The net radiation $(\mathrm{Rn})$ can be measured by a radiometer balance, but, in the absence of this instrument, it is common to estimate this climatic element with the aid of information obtained by a heliograph or pyranometer, which are usually installed in conventional and automatic weather stations, respectively. In Brazil, by the end of January 2011, the Brazilian National Institute of Meteorology (INMET) had 294 conventional weather stations and the insolation data were obtained in heliographs. There were also 453 automatic weather stations, of which, 422 recorded the shortwave radiation incident through pyranometers. INMET reported that the installation of the automatic ones sought answers, whenever possible, the synoptic scale $\left(1^{\circ} \times 1^{\circ}\right)$. From these INMET stations, the State of Minas Gerais (MG) has 51 conventional stations, 36 with heliographs and four with actinographs, and 53 automatic stations equipped with pyranometers. The State of Goiás (GO), on the other hand, owns 11 conventional stations, 10 with heliographs, none with actinographs, and 22 automatic stations with pyranometers.

Despite the increase in the number of automatic weather stations, which occurred in recent years in Brazil, as recorded for LIMA (2005), who reports that in 2005 there were only 72 automatic stations installed by INMET. It must be remembered that Brazil has about 8.5 million $\mathrm{km}^{2}$ and that the information collected by these stations are punctual. DI PACE et al. (2008) confirm this information stating that many instruments are able to measure with good accuracy the radiation balance, however, those considered as "conventional" provide punctual measurements of this term, which are representative only for small areas. When there is need to estimate this climate element over large areas, techniques based on measurements taken by satellite sensors are more appropriate because they comprise a large spatial coverage and have low operating cost.

PAIVA (2005) complements stating that due to the scarcity of data, it has become essential to use alternative techniques to complement weather information about a particular location. The remote sensing techniques have been widely used for information parameters of the atmosphere and surface, which are important for monitoring flows or parameters associated with regional and global scale, whose level of detail is determined by the spatial resolution of the multispectral sensors used. Among the sensing techniques, it is important to highlight the use of spaceborne sensors aboard environmental satellites, when it is desired to get information from large areas.

To obtain the net radiation at the surface, beyond the orbital information, it is necessary the use of algorithms, among them it is possible to mention SEBAL (Surface Energy Balance Algorithm for Land). In Brazil, the jobs from MENDONÇA (2007), ANDRADE (2008), DI PACE et al. (2008), NICÁCIO (2008), GOMES et al. (2009) and RODRIGUES et al. (2009) that were performed in different locations can be highlighted. It is noteworthy that most of these studies have used information from the TM (Thematic Mapper) sensor, aboard the Landsat-5, to determine the instantaneous net radiation, i.e., the value was estimated in the moment that the satellite passed over the location.

The radiation balance through SEBAL is the result of the accounting for shortwave radiation that focuses and reflects the surface, and incident long wave radiation, reflected and emitted by the surface. The $\mathrm{Rn}$ available to the surface is strongly influenced by the incident shortwave radiation, and is partitioned into power for air and soil temperatures change and to process the water phase change, which is sensible heat flows in the air $(\mathrm{H})$, sensible heat flow in the ground $(\mathrm{G})$ and latent heat flow $(\lambda E T)$, respectively. According to HEMAKUMARA et al. (2003), dividing the available energy to the surface in sensible heat flows in the air and ground, and latent is controlled by surface type and condition. Thus, the net radiation can be defined as the radioactive energy available at the surface, which is the main agent of many physical and biological processes. In this context, this work aims to determine the instantaneous and average, of 24 hours, radiation balance with the use of products of the MODIS (Moderate Resolution Imaging Spectrometer) sensor aboard the Terra satellite, in the sub-basins of the Entre Ribeiros creek e Preto River. 


\section{MATERIAL AND METHODS}

\section{Studied Area}

The Basin of Paracatu River is located in the Medium São Francisco region, and drains an area of approximately $45.600 \mathrm{~km}^{2}$, which means it is the second largest sub-basin of the São Francisco River. The sub-basins of Entre Ribeiros creek and Preto River, object of this study, represent about $30 \%$ of the Paracatu basin area. These two sub-basins, located in the Alto Paracatu region, cover the territories of the Federal District and the states of Goiás and Minas Gerais (Figure 1). According LATUF (2007), the sub-basins of the Entre Ribeiros creek and Preto river, Paracatu affluents, drain an area of approximately $14.149 \mathrm{~km}^{2}$, of which $74.87 \%\left(10.621 \mathrm{~km}^{2}\right)$ are located in the State of Minas Gerais, $15.71 \%\left(2.212 \mathrm{~km}^{2}\right)$ in the state of Goiás and $9.42 \%\left(1.316 \mathrm{~km}^{2}\right)$ in the Federal District.

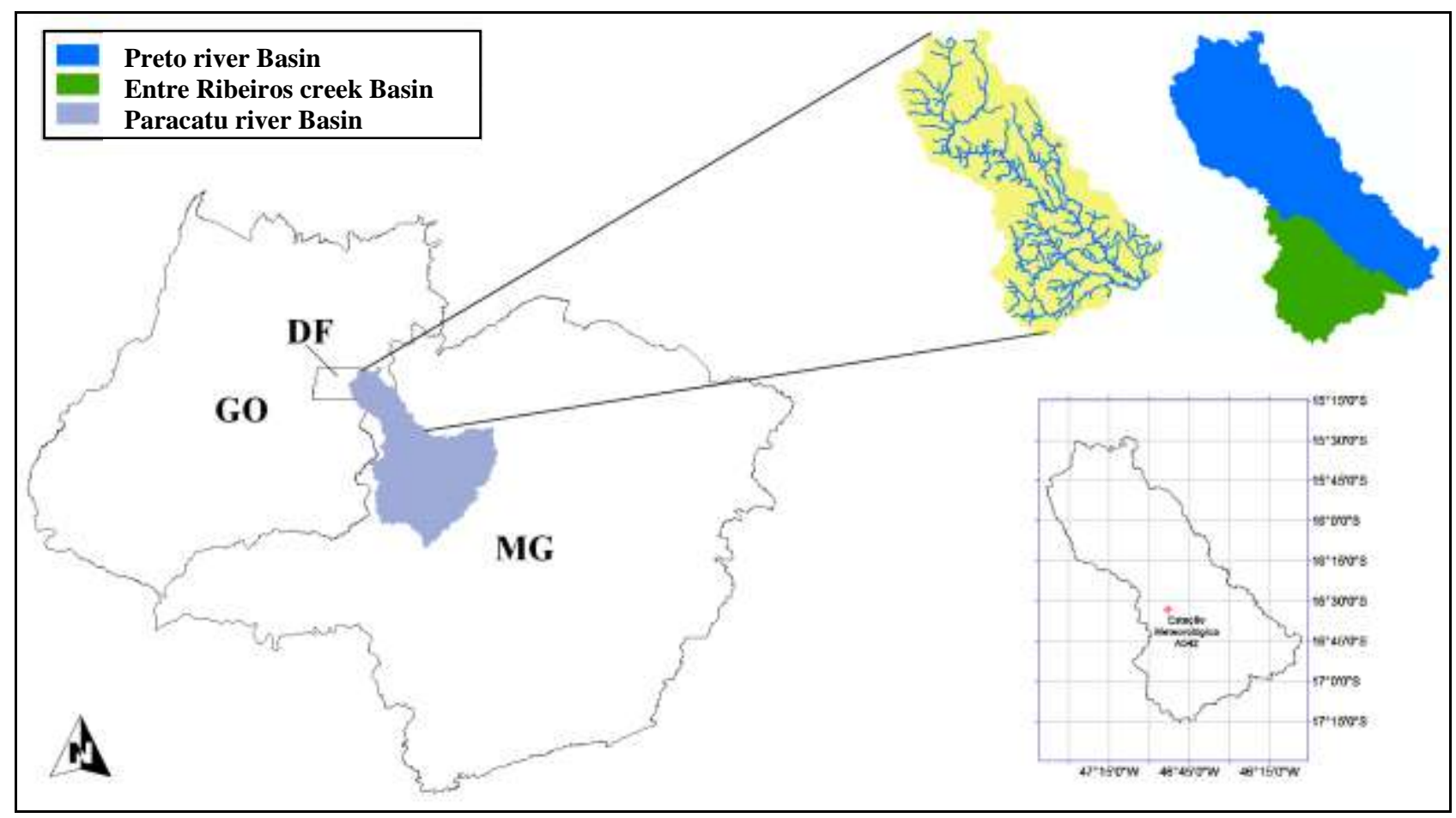

FIGURE 1. Location of the studied area. In the foreground, in grey, there is the Paracatu river basin, and, in the background, the studied sub-basins.

The climate of the Paracatu basin is predominantly tropical wet, with the rainy period from October to April, with emphasis on the period of November, December and January as the wettest. The annual rainfall average in the basin is $1.338 \mathrm{~mm}$, while the annual average evapotranspiration is 1.140mm (BRASIL, 1996).

The main uses of water resources in the sub-basins of the Entre Ribeiros creek and Preto river are to meet the demands of urban and animal water supply and irrigation. Most of the irrigated areas in the Paracatu basin are concentrated from the headwaters to half its draining system, especially in the Entre Ribeiros creek and Preto river, concentrating 53\% of the irrigated area in the basin identified by the Master Plan for the Paracatu Basin Water Resources - PLANPAR (BRASIL, 1996).

In the Preto river basin, the land use is characterized by intensive farming and high-tech mechanized agriculture, particularly the use of intensive center pivots in the irrigation process. BORGES (2008), using images from LANDSAT/ETM+ sensor of 2003, identified 226 pivots in the Preto river basin. Of these, 87 were located in the Federal District, 81 in Minas Gerais and 58 in Goiás. This author also states that the main activities developed in the basin are the milk and grains 
productions, in which the productions of corn, soybean, bean, sorghum, wheat and vegetables in general are highlighted.

\section{Data acquisition and processing}

The MODIS sensor products: MOD09GA (surface spectral reflectance, bands 1-7), MOD11A1 (surface temperature, bands 31 and 32) and MOD07 (zenith angle) of July 14 ${ }^{\text {th }}$, August $13^{\text {th }}$, September $16^{\text {th }}$ and October $16^{\text {th }}, 2007$ were obtained for free at the site http://reverb.echo.nasa.gov/reverb/ in HDF (Hierarchical Data Format) and converted to GeoTIFF using the program MRT (MODIS Reprojection Tool).

To calculate the instantaneous radiation net $\left(\mathrm{Rn}_{\text {inst. }}\right)$ it was used SEBAL. For such, it was determined the surface albedo $(\alpha)$, the incident shortwave radiation $\left(R_{s \downarrow}\right)$, the long wave radiation emitted by the atmosphere $\left(R_{L \downarrow}\right)$ and the long wave radiation emitted by the surface $\left(R_{L \uparrow}\right)$. For the complete description of the procedures used, see LIMA (2010).

The surface albedo was obtained from the reflectance bands altogether with the equation proposed by TASUMI et al. (2008).

$$
\alpha=0.215 \alpha_{1}+0.215 \alpha_{2}+0.242 \alpha_{3}+0.129 \alpha_{4}+0.101 \alpha_{5}+0.062 \alpha_{6}+0.036 \alpha_{7}
$$

where,

$\alpha 1, \alpha 2, \ldots$, and $\alpha 7$ - reflectance bands of the MOD09GA product.

The incident shortwave radiation, defined as the flow of direct and diffuse solar radiation that reaches the Earth's surface, was estimated for clear sky condition (ALLEN et al., 2002).

$$
\mathrm{R}_{\mathrm{s} \downarrow}=G_{s c} \cdot \cos \theta \cdot \mathrm{d}_{\mathrm{r}} \cdot \tau_{\mathrm{sw}}
$$

where,

Gsc - solar constant (1367W.m $\left.{ }^{-2}\right)$;

$\theta$ - zenithal angle, obtained from the MOD07 product;

$\mathrm{d}_{\mathrm{r}}$ - inverse square of the Earth-Sun relative distance;

$\tau_{\mathrm{sw}}-$ atmospheric transmissivity.

The long wave radiation emitted by the atmosphere towards the surface (Equation 3) was calculated by the Stefan-Boltzmann equation.

$$
\mathrm{R}_{\mathrm{L} \downarrow}=\varepsilon_{\mathrm{a}} \cdot \sigma \cdot\left(\mathrm{T}_{\text {cold pixel }}\right)^{4}
$$

where,

$$
\begin{aligned}
& \varepsilon_{\mathrm{a}}-\text { atmospheric emissivity (dimensionless); } \\
& \sigma-\text { Stefan-Boltzmann constant }\left(\sigma=5.67 \times 10^{-8} \mathrm{~W} \cdot \mathrm{m}^{-2} \cdot \mathrm{K}^{-4}\right) \\
& \mathrm{T}_{\text {cold pixel }} \text { - cold pixel temperature }(\mathrm{K}) .
\end{aligned}
$$

The long wave radiation emitted by the surface was achieved through the Stefan-Boltzmann equation, according to the following expression:

$$
\mathrm{R}_{\mathrm{L} \uparrow}=\varepsilon_{0} \cdot \sigma \cdot \mathrm{T}_{\mathrm{s}}^{4}
$$

where,

$\varepsilon_{o}$ - surface emissivity (dimensionless);

$\mathrm{T}_{\mathrm{s}}$ - surface temperature (K), obtained from the MOD11A1 product. 
The net radiation records the available radiant power and it is function of the components coming to and from the soil surface. This term, in its instantaneous shape, was obtained by the following expression (ALLEN et al. 2002):

$$
R n_{\text {inst. }}=R_{s \downarrow}-\alpha R_{s \downarrow}+R_{L \downarrow}-R_{L \uparrow}-\left(1-\varepsilon_{o}\right) R_{L \downarrow}
$$

where,

$\mathrm{Rn}_{\text {inst. }}-$ instantaneous net radiation $\left(\mathrm{W} \cdot \mathrm{m}^{-2}\right)$.

To obtain the average net radiation occurred in a period of 24 hours $\left(\mathrm{W} \cdot \mathrm{m}^{-2} \cdot \mathrm{d}^{-1}\right)$, it was used the TEIXEIRA et al. (2009) expression mentioned by LIMA (2010).

$$
R n_{24 h}=(1-\alpha) R s_{24 h}-143.1 \tau_{s w 24 h}
$$

where,

$$
\begin{aligned}
& \mathrm{Rs}_{24 \mathrm{~h}}-\text { daily incident shortwave radiation }\left(\mathrm{W} \cdot \mathrm{m}^{-2} \cdot \mathrm{d}^{-1}\right) ; \\
& \tau_{\mathrm{sw} 24 \mathrm{~h}} \text { - daily atmospheric transmissivity (dimensionless). }
\end{aligned}
$$

The incident shortwave radiation data, from the days listed in the study, were obtained from the automatic weather station (A542) located in the city of Unaí, Minas Gerais, as observed in Figure 1. These data were used as input data in SEBAL to estimate the average net radiation occurred in a period of 24 hours. The data were obtained at the site http://www.inmet.gov.br/portal/index.php?r=estacoes/estacoesAutomaticas. The station used in this study has the following geographical coordinates: latitude $16^{\circ} 33^{\prime} 14^{\prime \prime}$ South, longitude 46 $52 ' 55^{\prime \prime}$ West and $631 \mathrm{~m}$ of altitude, and belongs to INMET automatic stations network.

\section{RESULTS AND DISCUSSION}

The surface albedo estimated using the information of MOD09GA product (spectral reflectance of the surface) is shown in Figure 2 for the areas of the sub-basins of the Entre Ribeiros creek and Preto river. The albedo exerts a control on the amount of energy that is absorbed by the Earth's surface, acting in net radiation and in the consequent energy balance.

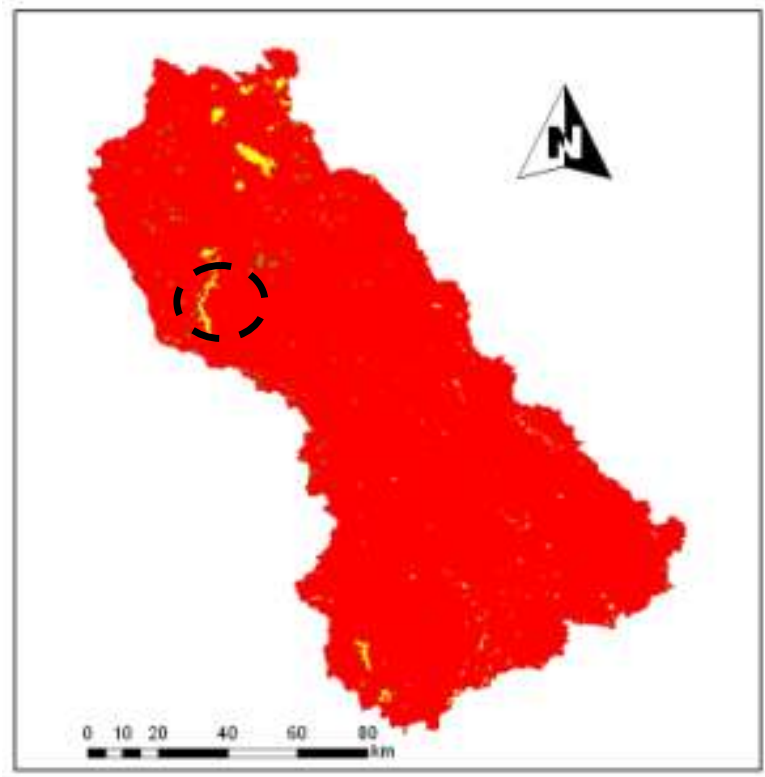

(a)

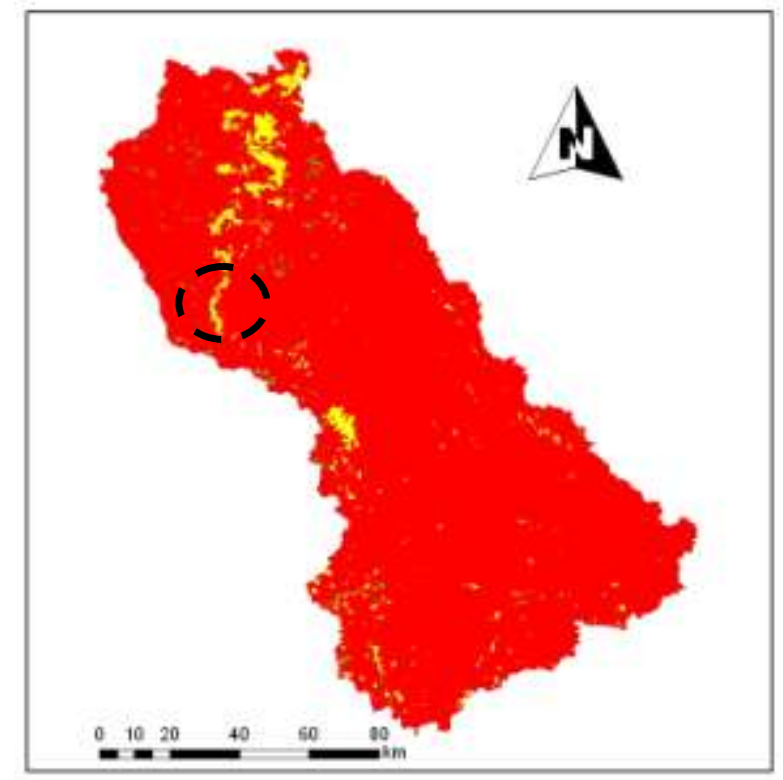

(b) 


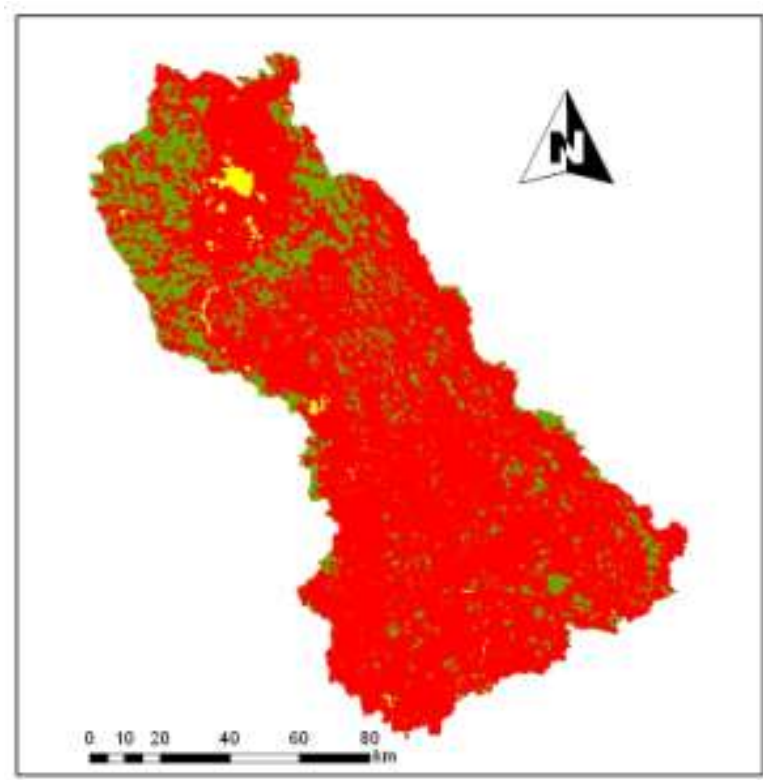

(c)

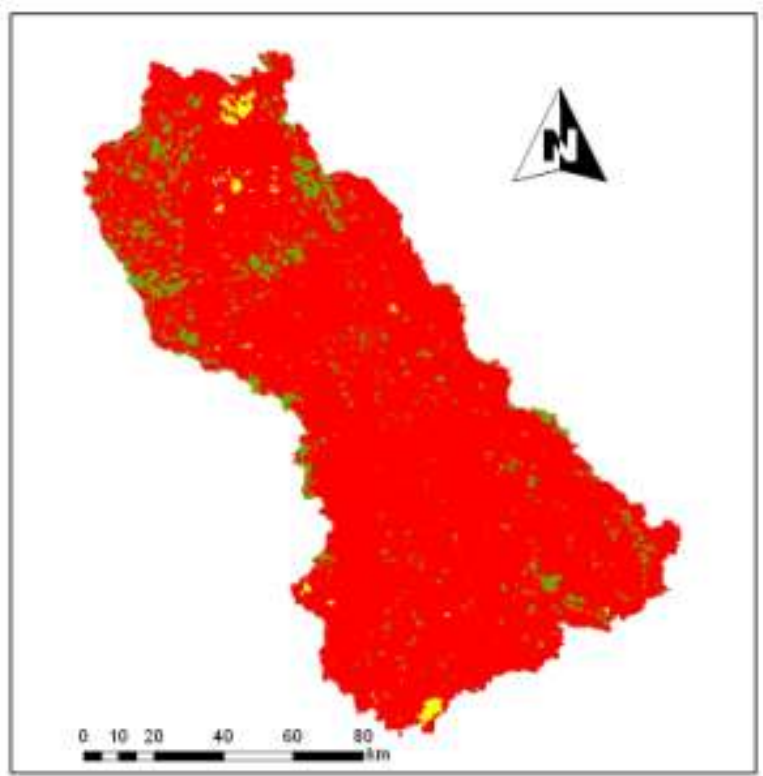

(d)

$$
0,00-0,1 \square 0,11-0,2 \square 0,21-0,3 \square 0,31-0,4
$$

FIGURE 2. Surface albedo (dimensionless) for July $14^{\text {th }}$ (a), August $13^{\text {th }}(\mathrm{b})$, September $16^{\text {th }}$ (c) and October $16^{\text {th }}(d), 2007$.

It was found some homogeneity in the comparison of the albedo maps, except for the areas located mainly in the upper Preto river region. Mostly of the thematic maps $\alpha$ ranged between 0.11 and 0.2 (red), but there were some areas in the upper Preto river region (Figures $2 \mathrm{a}$ and $2 \mathrm{~b}$ ) in which the albedo was lower, i.e., between 0.0 and 0.1. However, in some areas of that part of the Preto river basin (Figures $2 \mathrm{c}$ and $2 \mathrm{~d}$ ), there was an increase in the surface albedo, which ranged between 0.21 and 0.3. According to HARTMANN (1994) mentioned by LIMA (2010), the albedo for vegetated surfaces depends on the soil texture and physiological conditions of the plant canopy. Dry soils have a significantly larger albedo than those observed in wet soils, while a smooth surface has greater albedo than a rough one, since they have the same material. As seen in Table 1, the average surface albedo varied between 0.14 and 0.17 , with a minimum value of 0.02 on July ${ }^{14 \text { th }}$ and August $13^{\text {th }}$, and a maximum of 0.31 on August $13^{\text {th }}$ and September $16^{\text {th }}, 2007$.

TABLE 1. Minimum, medium and maximum values of the surface albedo $(\alpha)$, instantaneous net radiation $\left(\mathrm{Rn}_{\text {inst. }}\right)$ and average net radiation occurred in a period of 24 hours $\left(\mathrm{Rn}_{24 \mathrm{~h}}\right)$ observed in geospatial imagery.

\begin{tabular}{cccccccccc}
\hline & \multicolumn{3}{c}{$\alpha($ dimensionless) } & \multicolumn{3}{c}{$\mathbf{R n}_{\text {inst. }}\left(W . \mathbf{m}^{-\mathbf{2}}\right)$} & \multicolumn{3}{c}{$\mathbf{R n}_{\mathbf{2 4 h}}\left(\mathbf{W . m}^{-\mathbf{2}} \mathbf{d}^{\mathbf{- 1}}\right)$} \\
\hline Dates & Minimum & Medium & Maximum & Minimum & Medium & Maximum & Minimum & Medium & Maximum \\
\hline $\mathbf{0 7 / 1 4}$ & 0.02 & 0.14 & 0.26 & 419.13 & 509.41 & 632.91 & 67.75 & 95.99 & 122.60 \\
\hline $\mathbf{0 8} / \mathbf{1 3}$ & 0.02 & 0.14 & 0.31 & 445.88 & 582.81 & 736.72 & 78.30 & 123.34 & 153.45 \\
\hline $\mathbf{0 9 / 1 6}$ & 0.03 & 0.17 & 0.31 & 422.80 & 565.96 & 757.58 & 98.12 & 136.27 & 175.99 \\
\hline $\mathbf{1 0} / 16$ & 0.05 & 0.16 & 0.30 & 501.80 & 643.33 & 797.35 & 124.55 & 168.07 & 202.73 \\
\hline Average & $\mathbf{0 . 0 3}$ & $\mathbf{0 . 1 5}$ & $\mathbf{0 . 3 0}$ & $\mathbf{4 4 7 . 4 0}$ & $\mathbf{5 7 5 . 3 8}$ & $\mathbf{7 3 1 . 1 4}$ & $\mathbf{9 2 . 1 8}$ & $\mathbf{1 3 0 . 9 2}$ & $\mathbf{1 6 3 . 6 9}$ \\
\hline
\end{tabular}

MENDONÇA (2007) estimated the instantaneous Rn for the Norte Fluminense region, State of Rio de Janeiro, using products from the MODIS sensor, and found values between 411.76 and $646.64 \mathrm{~W} . \mathrm{m}^{-2}$ on August $29^{\text {th }}, 2005,499.06$ and $873.28 \mathrm{~W} \cdot \mathrm{m}^{-2}$ on November $16^{\text {th }}, 2005,482.40$ and $818.32 \mathrm{~W} . \mathrm{m}^{-2}$ on February $5^{\text {th }}, 2006$, and 270.04 and $438.72 \mathrm{~W} \cdot \mathrm{m}^{-2}$ on June $15^{\text {th }}, 2006$. Although 
these two locations are in different latitudes, the Rn minimum of $419.13 \mathrm{~W} \cdot \mathrm{m}^{-2}$, found in this study, was consistent with that one from MENDONÇA (2007) on August 29 ${ }^{\text {th }}, 2005$, and the Rn maximum of $797.35 \mathrm{~W} . \mathrm{m}^{-2}$ found for the sub-basins of the Entre Ribeiros creek and Preto river, was compatible with the one from MENDONÇA (2007) on February $5^{\text {th }}, 2006$.

NICÁCIO (2008) estimated the surface albedo for October $12^{\text {th }}, 2004$, in the region of Petrolina/Juazeiro, in Brazil, using the MODIS in the satellite Aqua, and noted that the albedo values were less than $13 \%$ over the São Francisco river. After the "water" class, the lowest values of albedo occurred over the region occupied by dense savanna steppe, with values between 0.13 and 0.17 , while open areas with native vegetation showed values around 0.17 to 0.20 . The author mentions that regions occupied by productions of irrigated fruit showed albedo values ranging especially from 0.22 to 0.25 , and the highest values of albedo occurred in urbanized areas, such as the city of Petrolina, state of Pernambuco (PE), with values greater than $27 \%$.

The results found by MENDONÇA (2007) and NICÁCIO (2008) served to compare the results of the albedo found for the two sub-basins of the Paracatu river. It will be highlighted the minimum values found by MENDONÇA (2007), because from the analysis of these results, it was concluded that the author may have set a condition at the time of processing through SEBAL, so that the minimum value of the albedo was 0.0 in different dates. Although the soil cover, the dates and time of the satellite imagery of the surface were distinct to the regions of Paracatu and Norte Fluminense, RJ, the maximum albedo of 0.31, found in the sub-basins of Paracatu, was compatible with the one from MENDONÇA (2007) on January $15^{\text {th }}, 2006$. To complement, the albedo found for part of the Preto river (yellow), in the areas circled in black (Figures 2a and 2b), is similar to the result found by NICÁCIO (2008) in the riverbed of the São Francisco river.

The instantaneous net radiation ( $\mathrm{R}_{\text {ninst. }}$ ) estimated by SEBAL using MODIS sensor information is presented in Figure 3 for the areas of the sub-basins of the Entre Ribeiros creek and Preto river. The spatial variation of net radiation observed in thematic maps is explained by the surfaces present in the sub-basins of the Entre Ribeiros creek and Preto river (savannah, grassland, irrigated areas with different types of crops, waterways, etc.), because the surface albedo - shortwave balance modeler varies according to the physicochemical characteristics of the surfaces and the zenithal angle.

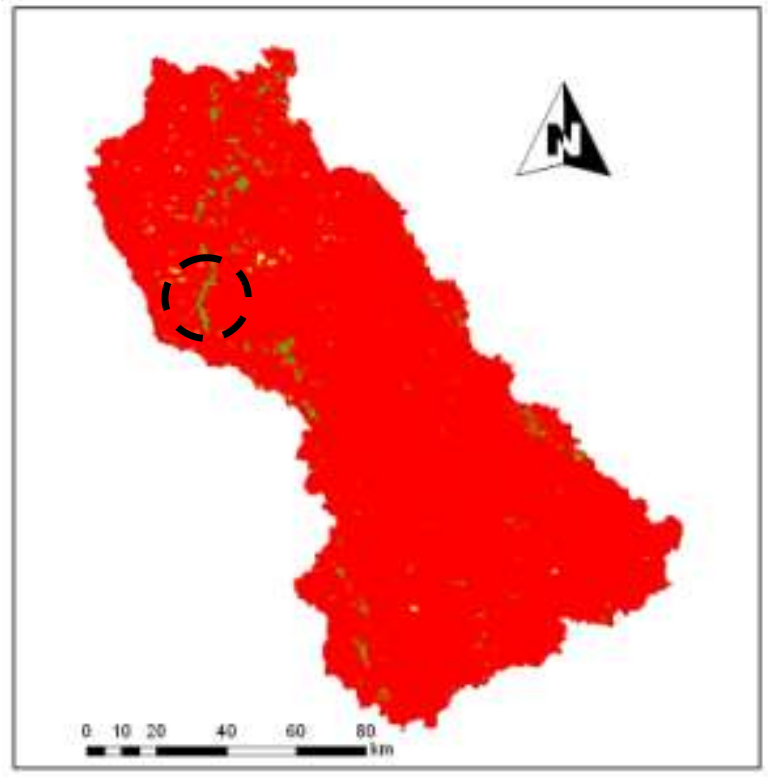

(a)

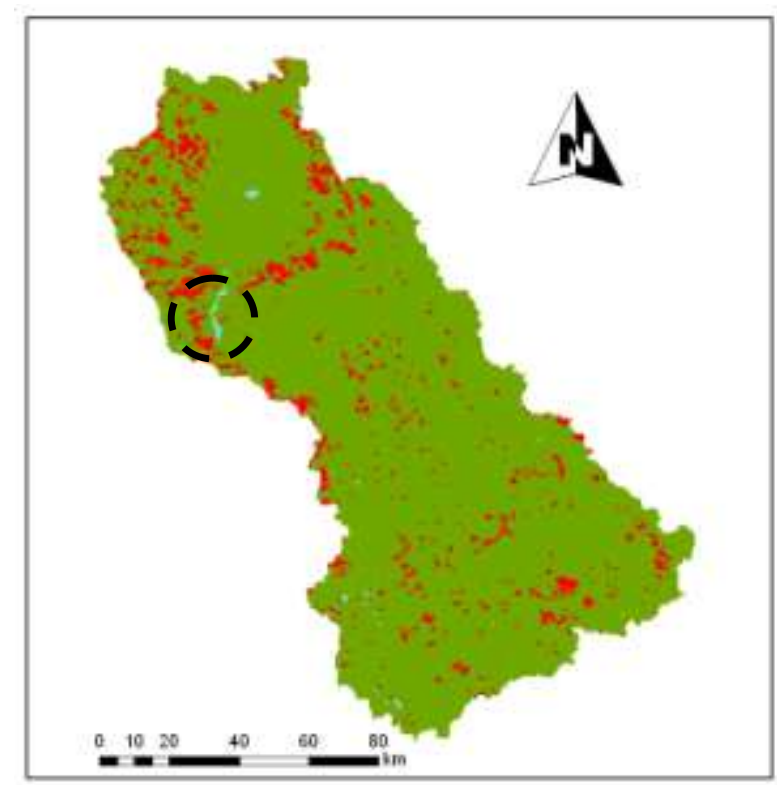

(b) 


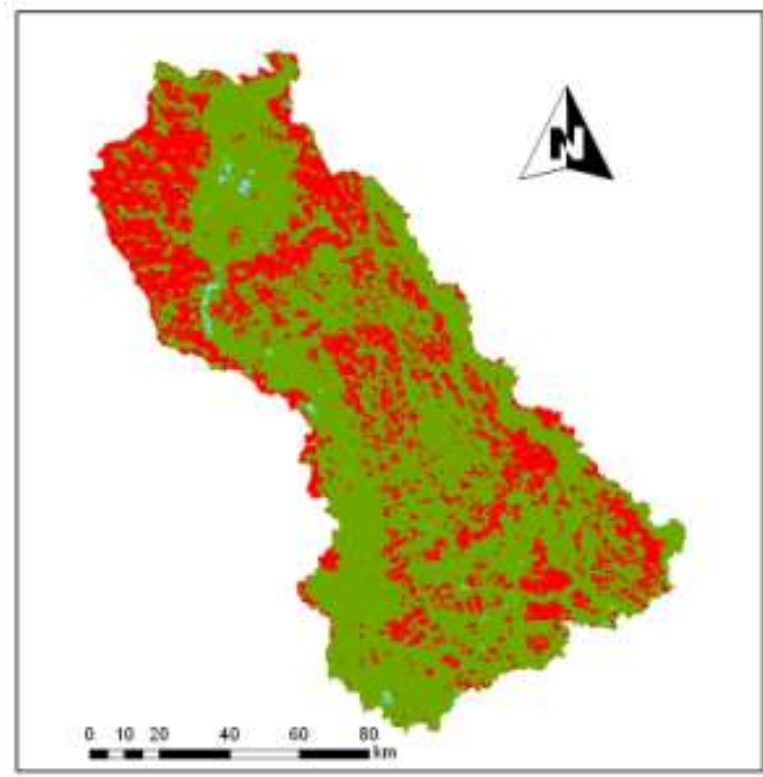

(c)

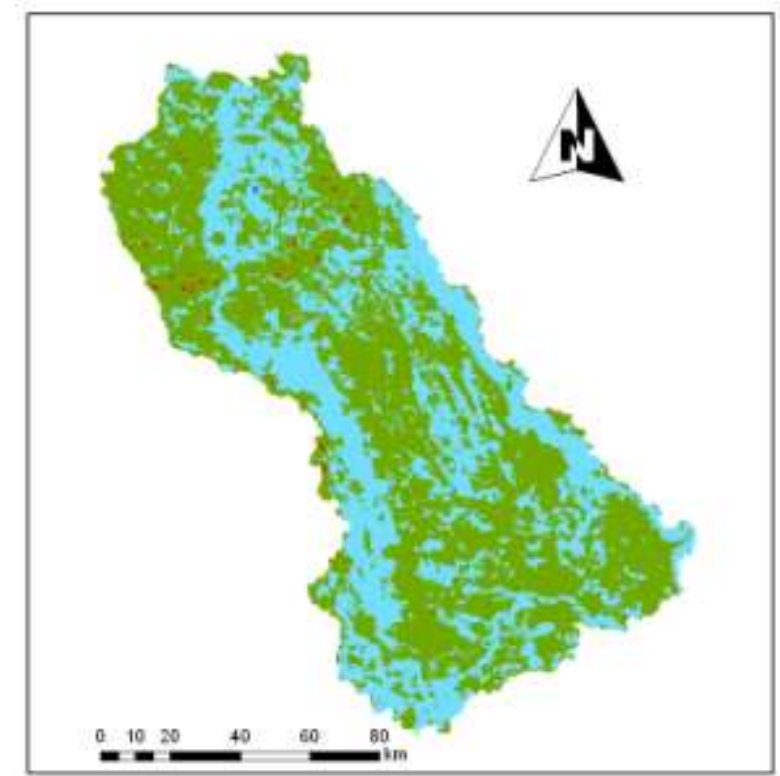

(d)

$450 \square 451-550 \square 551-650 \square 651-750 \square \square 751$

FIGURE 3. Instantaneous net radiation $\left(\mathrm{W} \cdot \mathrm{m}^{-2}\right)$ for July $14^{\text {th }}(\mathrm{a})$, August $13^{\text {th }}(\mathrm{b})$, September $16^{\text {th }}$ (c) and October $16^{\text {th }}(\mathrm{d}), 2007$.

None of the thematic maps can clearly show the hydrography of the sub-basins. This was due to spatial resolution of each pixel $(500 \mathrm{~m} \times 500 \mathrm{~m})$ that composes the map; sometimes the pixel information is the combination of different surfaces that makes up the pixel area in question. Due to the spatial resolution of MODIS, an element of the scene corresponding to a pixel of the image can include more than one type of ground cover. When a sensor observes the scene, the detected radiance is integration, called mixture of all objects contained in the scene element (AGUIAR et al., 1999).

Despite the hydrography of the sub-basins is not fully present in thematic maps, it was observed that the values of the instantaneous net radiation were high on liquid surfaces when compared to other types of surface. To illustrate this statement, there are areas circled in black (Figures $3 \mathrm{a}$ and $3 \mathrm{~b}$ ), which shows high values of $\mathrm{Rn}$ from part of the Preto river. According to LIMA et al. (2009), the trend of higher values of $\mathrm{Rn}$ on liquid surfaces and less on other types of surfaces can be explained by the combined effect of albedo and surface temperature, because the first one influences the balance of shortwaves and second one, the balance of long waves.

LIMA et al. (2009) complement saying that a lower surface albedo $(\alpha)$, situation observed on the liquid surface, favors a low reflection of shortwave radiation, thus contributing to the balance of shortwaves be larger as compared with a surface area of greater reflection, i.e., higher albedo surfaces. Whereas, a lower surface temperature (Ts), situation observed on liquid surfaces, promotes a lower balance of long waves in terms of absolute value, as compared to surfaces with higher temperatures. They conclude by saying that a lower value of $\alpha$ and Ts favors that $\mathrm{Rn}$ be higher on liquid surfaces.

Comparing the four maps of Figure 3 it is possible to see the increase in the instantaneous net radiation, especially when observing Figure $3 \mathrm{~d}$, with the presence of many areas with values greater than $651 \mathrm{~W} . \mathrm{m}^{-2}$, and compares it to $3 \mathrm{a}$. This trend can be explained by the seasonality of the incident shortwave radiation, which varies with the solar declination. In most thematic maps $\mathrm{Rn}$ ranged between 451 and $650 \mathrm{~W} \cdot \mathrm{m}^{-2}$ (red and green), but there were some areas in the upper Preto river region (Figure 3a) with the net radiation lesser than $450 \mathrm{~W} \cdot \mathrm{m}^{-2}$ (yellow). The instantaneous net 
radiation average ranged between 509.41 and $643.33 \mathrm{~W} . \mathrm{m}^{-2}$, with a minimum value of $419.13 \mathrm{~W} . \mathrm{m}^{-2}$ on July $14^{\text {th }}$ and a maximum of $797.35 \mathrm{~W} . \mathrm{m}^{-2}$ on October $16^{\text {th }}, 2007$, as presented in Table 1 .

MENDONÇA (2007) estimated the instantaneous Rn for the Norte Fluminense region, State of Rio de Janeiro, using images from the MODIS sensor, and found values between 410 and $650 \mathrm{~W} . \mathrm{m}^{-2}$ on August $29^{\text {th }}, 2005,500$ and $870 \mathrm{~W} . \mathrm{m}^{-2}$ on November $16^{\text {th }}, 2005,480$ and $820 \mathrm{~W} . \mathrm{m}^{-2}$ on February $5^{\text {th }}, 2006$, and 270 and $440 \mathrm{~W} . \mathrm{m}^{-2}$ on June $15^{\text {th }}, 2006$. Although these two locations are in different latitudes, the Rn minimum of $419.13 \mathrm{~W} . \mathrm{m}^{-2}$, found in this study, was consistent with that one from MENDONÇA (2007) on August $29^{\text {th }}, 2005$, and the Rn maximum of $797.35 \mathrm{~W} . \mathrm{m}^{-2}$ found for the sub-basins of the Entre Ribeiros creek and Preto river, was compatible with the one from MENDONÇA (2007) on February $5^{\text {th }}, 2006$.

ATAÍDE (2006) estimated the instantaneous Rn for the city of Quixeré, in the state of Ceará (CE), in Brazil, using information from the MODIS sensor, aboard the Terra satellite, on four different days, and found values between 719 and $848 \mathrm{~W} \cdot \mathrm{m}^{-2}$ on September $10^{\text {th }}, 2005,733$ and $864 \mathrm{~W} \cdot \mathrm{m}^{-2}$ on October $10^{\text {th }}, 2005,686$ and $817 \mathrm{~W} \cdot \mathrm{m}^{-2}$ on October $14^{\text {th }}, 2005$, and between 661 and $809 \mathrm{~W} . \mathrm{m}^{-2}$ on October $25^{\text {th }}, 2005$. It was found that the maximum value of instantaneous $\mathrm{Rn}$ of $797.35 \mathrm{~W} . \mathrm{m}^{-2}$, estimated for the sub-basins of the Entre Ribeiros creek and Preto river, was consistent with those found in the city of Quixeré, CE, on October $14^{\text {th }}$ e $25^{\text {th }}, 2005$. However, the minimum value of instantaneous $\mathrm{Rn}$ of $419.13 \mathrm{~W} . \mathrm{m}^{-2}$, found for the Paracatu river region, was always less than those from the city of Quixeré, CE. This difference may be due to the surface albedo, because a change in this term directly affects the net radiation. It is worth noting that $\alpha$ depends on the angle of incidence of solar radiation and surface conditions such as soil color, moisture, coating type and stage of crop development. Another issue that must be considered to explain the difference in the minimum values of this study and those found by ATAÍDE (2006) are the methodological differences in the determination of Rn.

The results found by MENDONÇA (2007) and ATAÍDE (2006) served to compare the results of the instantaneous radiation found for the two sub-basins of the Paracatu river, since the automatic weather station (A542), located in the municipality of Unaí, MG, lacked balance radiometer. Usually, weather stations have no balance radiometers, which, due to the purchase cost, are often restricted to experimental campaigns.

In the absence of information from the net radiation, LIMA (2010) used data from incident shortwave radiation $\left(R_{s \downarrow}\right)$, collected by an automatic station, to check the behavior of this component estimated using the SEBAL. LIMA (2010) states that the values of incident solar radiation estimated by SEBAL algorithm showed a good correlation $\left(r^{2}=0.92\right)$ with the values measured at the weather station, but there was a tendency to overestimate. The root-mean-square error (RMSE) was 47.00W. $\mathrm{m}^{-2}$ and the mean absolute error (MAE) was $39.36 \mathrm{~W} . \mathrm{m}^{-2}$.

The average net radiation occurred within 24 hours $\left(\mathrm{Rn}_{24 \mathrm{~h}}\right)$ estimated by the SEBAL using information from the MODIS sensor is presented in Figure 4 for the areas of the sub-basins of the Entre Ribeiros creek and Preto river. To determine this term, it was necessary the incident shortwave radiation data, obtained in the automatic weather station in the city of Unaí, MG, and the atmospheric transmissivity data presented in Table 2.

TABLE 2. Daily incident shortwave radiation values $\left(\mathrm{Rs}_{24 \mathrm{~h}}\right)$ and daily atmospheric transmissivity $\left(\tau_{\mathrm{sw} 24 \mathrm{~h}}\right)$.

\begin{tabular}{ccc}
\hline Dates & $\operatorname{Rs}_{\mathbf{2 4 h}}\left(\mathbf{W} \cdot \mathbf{m}^{-\mathbf{2}} \cdot \mathbf{d}^{-\mathbf{1}}\right)$ & $\boldsymbol{\tau}_{\text {sw24h }}($ dimensionless $)$ \\
\hline $\mathbf{0 7 / 1 4}$ & 224.58 & 0.68 \\
$\mathbf{0 8 / 1 3}$ & 260.36 & 0.71 \\
$\mathbf{0 9 / 1 6}$ & 279.47 & 0.66 \\
$\mathbf{1 0 / 1 6}$ & 318.33 & 0.69 \\
\hline
\end{tabular}




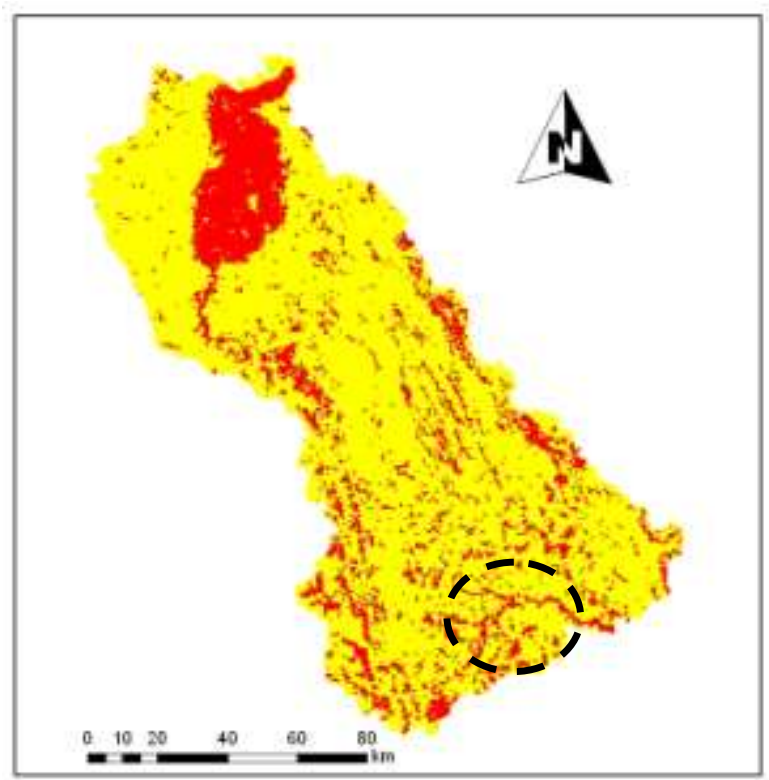

(a)

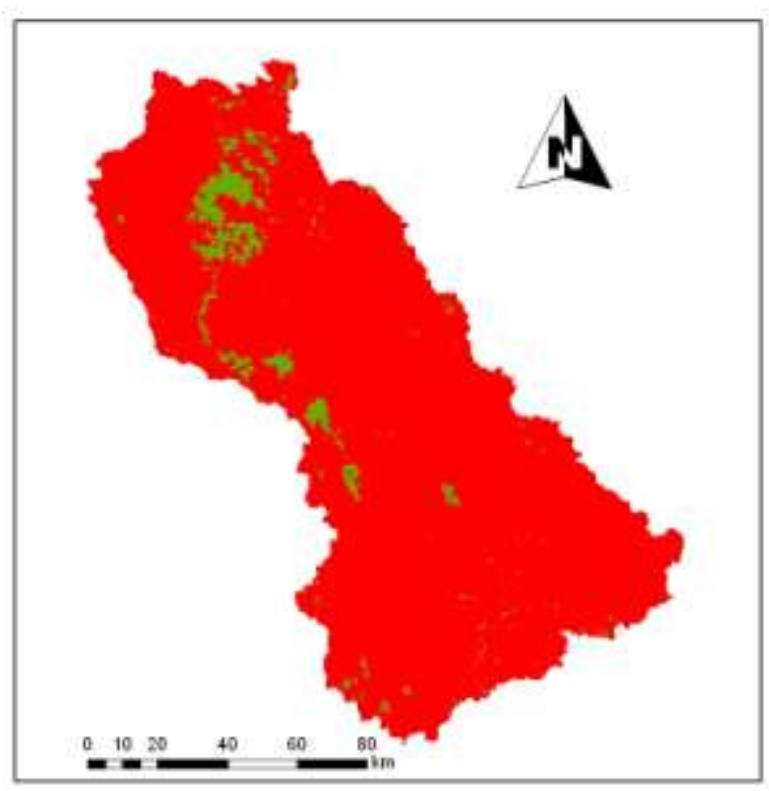

(c)

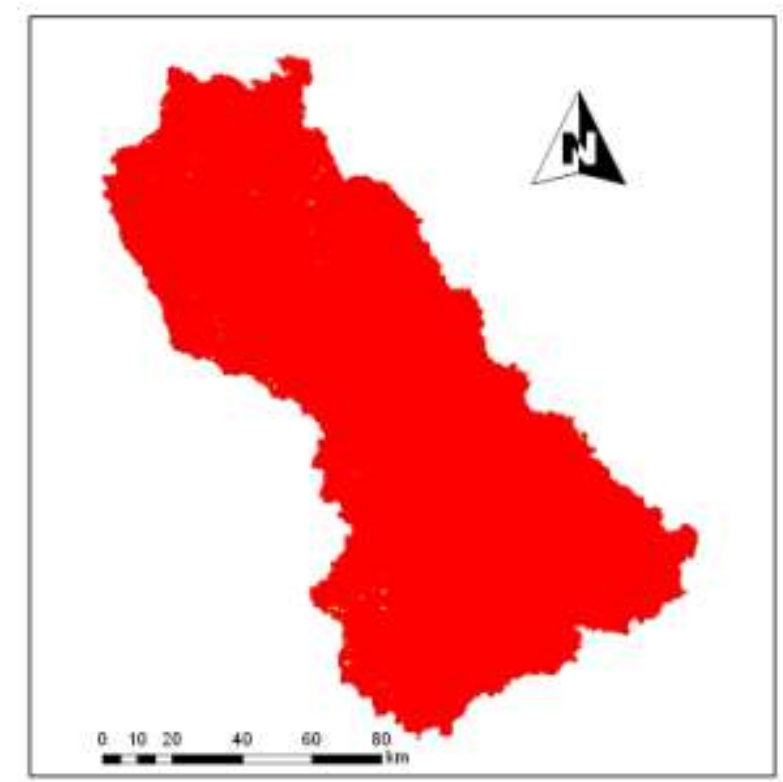

(b)

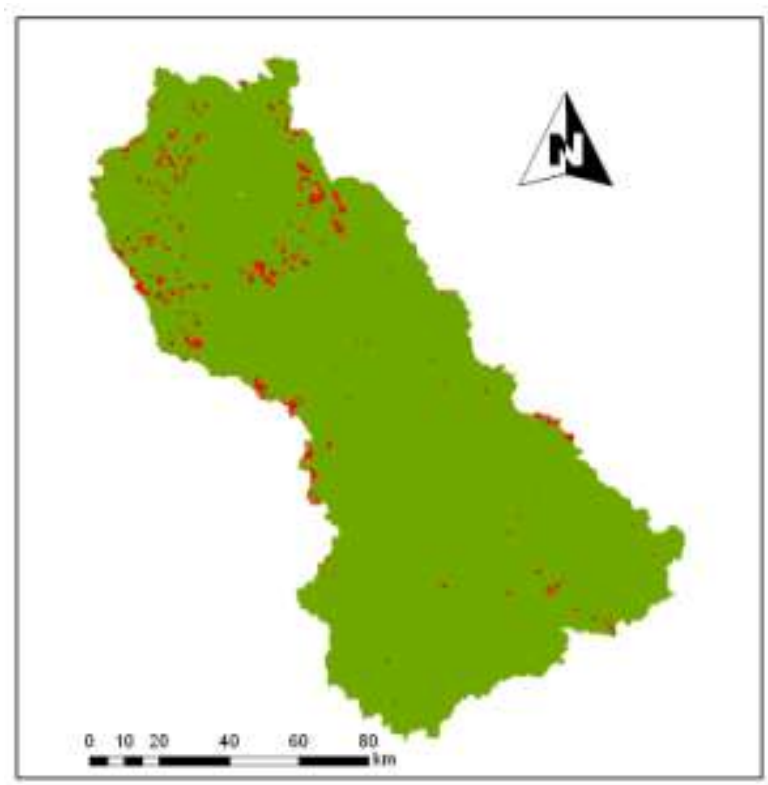

(d)

$\square<100 \square 101-150 \square 151-200 \square>201$

FIGURE 4. Average net radiation in a period of 24 hours $\left(W \cdot m^{-2}\right.$ ) for July $14^{\text {th }}$ (a), August $13^{\text {th }}$ (b), September $16^{\text {th }}(\mathrm{c})$ and October $16^{\text {th }}(d), 2007$.

Comparing the thematic maps there has been an increase in the average net radiation for 24 hours, especially when it is observed in Figure 4d. This behavior is explained mainly by increasing the daily incident shortwave radiation, as observed in Table 2 that over time is a function of the solar declination. However, the daily atmospheric transmissivity, ranging between 0.66 in 09/16 and 0.71 in $08 / 13$, had little influence on the increase in average net radiation for 24 hours.

Thematic maps of $\mathrm{Rn}_{24 \mathrm{~h}}$, except for some areas, showed homogeneous conditions. On July $14^{\text {th }}$ (Figure 4a), although mostly of the sub-basins of the Entre Ribeiros creek and Preto river present the $\mathrm{Rn}_{24 \mathrm{~h}}$ less than $100 \mathrm{~W} \cdot \mathrm{m}^{-2} \cdot \mathrm{d}^{-1}$ (yellow), some areas showed the $\mathrm{Rn}_{24 \mathrm{~h}}$ between 101 and $150 \mathrm{~W} \cdot \mathrm{m}^{-2} \cdot \mathrm{d}^{-1}$, which is the case occurred on the Entre Ribeiros creek and São Pedro, shown by the area circled in black. In $4 \mathrm{~b}$ and $4 \mathrm{c}$, the predominance of $\mathrm{Rn}_{24 \mathrm{~h}}$ between 101 and $150 \mathrm{~W} \cdot \mathrm{m}^{-2} \cdot \mathrm{d}^{-1}$ was higher, with the exception of some areas in the middle and upper Preto river region (Figure $4 \mathrm{c}$ ). On 
October $16^{\text {th }}$ the $\mathrm{Rn}_{24 \mathrm{~h}}$ predominant range was higher than the verified in previous maps, i.e., $\mathrm{Rn}_{24 \mathrm{~h}}$ ranged between 151 and $200 \mathrm{~W} \cdot \mathrm{m}^{-2} \cdot \mathrm{d}^{-1}$ (green). As seen in Table 1, the average net radiation for 24 hours was between 95.99 and $168.07 \mathrm{~W} . \mathrm{m}^{-2} \cdot \mathrm{d}^{-1}$, with a minimum value of $67.75 \mathrm{~W} . \mathrm{m}^{-2} \cdot \mathrm{d}^{-1}$ on July $14^{\text {th }}$ and a maximum of $202.73 \mathrm{~W} \cdot \mathrm{m}^{-2} \cdot \mathrm{d}^{-1}$ on October $16^{\text {th }}, 2007$.

OLIVEIRA et al. (2006) conducted a study in an area of native savanna vegetation in the city of Petrolina, in the state of Pernambuco, Brazil. These authors found that the seasonal variation of radiation accompanies the seasonal variation of incident shortwave radiation. The minimum values of net radiation were observed in July, whose daily averages did not exceed $150 \mathrm{~W} . \mathrm{m}^{-2}$, reaching values slightly above 200W. $\mathrm{m}^{-2}$ in February. The sub-basins of the Entre Ribeiros creek and Preto river have various types of surfaces, such as savannah, grasslands, streams and irrigated areas with different crops, and this may be the reason for the minimum value of $67.75 \mathrm{~W} . \mathrm{m}^{-2} \cdot \mathrm{d}^{-1}$, found in the sub-basins in the study of Paracatu be lower than the values found by OLIVEIRA et al. (2006).

The knowledge of the radiation is essential for estimating water loss by vegetated surfaces, and it is necessary for the planning of agricultural activities. In this context, the results of instantaneous and average radiation for 24 hours are important. In the absence of such information the SEBAL algorithm can determine them, since the results were consistent with various locations, like those cited in the literature.

Many areas of Brazil do not have or have disabilities of automatic weather stations with balance radiometers. The sub-basins of the Entre Ribeiros creek and Preto river, which together have a considerable area, with approximately $15.000 \mathrm{~km}^{2}$, and have only one INMET automatic station, depict well this situation. FIETZ \& FISCH (2009) complement mentioning that most of the weather stations in Brazil do not have the instruments to measure the net radiation, because the radiometers balance present high cost and difficulties in maintenance.

\section{CONCLUSIONS}

The highest values of average net radiation and instantaneous net radiation for 24 hours occurred on liquid surfaces, and lower values on other types of surfaces, such as savannah, pasture and irrigated areas with different crops and stages of development.

The results of net radiation found by the SEBAL algorithm are important because it can estimate them when there is deficiency of automatic weather stations, especially when there is no radiometers balance. This condition reflects the sub-basins of the Entre Ribeiros creek and Preto river, which together have a considerable area and only one automatic station, that belongs to INMET, without a radiometer balance.

\section{REFERENCES}

AGUIAR, A.P.D.; SHIMABUKURO, Y.E.; MASCARENHAS, N.D.A. Use of synthetic bands derived from mixing models in the multispectral classification of remote sensing images. International Journal of Remote Sensing, Basingstoke, v.20, n.4, p.647-657, 1999.

ALLEN, R.G.; TREZZA, R.; TASUMI, M. Surface energy balance algorithms for land. Advance training and users manual, version 1.0.2002.98 p.

ANDRADE, R.G. Aplicação do algoritmo Sebal na estimativa da evapotranspiração e da biomassa acumulada da cana-de-açúcar. 2008. 135 f. Tese (Doutorado em Meteorologia Agrícola) Universidade Federal de Viçosa, Viçosa, 2008.

ATAIIDE, K.R.P. Determinação do saldo de radiação e radiação solar global com produtos do sensor MODIS Terra e Aqua. 2006. 88 f. Dissertação (Mestrado em Meteorologia) - Universidade Federal de Campina Grande, Campina Grande, 2006. 
BORGES, M.E.S. Mapeamento geomorfológico da bacia do rio Preto e sua relação com o uso agrícola. 2008. 68 f. Dissertação (Mestrado em Geografia) - Universidade de Brasília, Brasília, 2008.

BRASIL. Ministério do Meio Ambiente. Plano diretor de recursos hídricos da Bacia do Rio Paracatu. Brasília: PLANPAR, 1996. V.1, t. 1. CD-ROM.

DI PACE, F.T.; SILVA, B.B.; SILVA, V.P.R.; SILVA, S.T.A. Mapeamento do saldo de radiação com imagens Landsat 5 e modelo de elevação digital. Revista Brasileira de Engenharia Agrícola e Ambiental, Campina Grande, v.12, n.4, p.385-392, 2008.

FIETZ, C.R.; FISCH, G.F. Avaliação de modelos de estimativa do saldo de radiação e do método de Priestley-Taylor para a região de Dourados, MS. Revista Brasileira de Engenharia Agrícola e Ambiental, Campina Grande, v.13, n.4, p.449-453, 2009.

GOMES, H.B.; SILVA, B.B.; CAVALCANTI, E.P.; ROCHA, H.R. Balanço de radiação em diferentes biomas no Estado de São Paulo mediante imagens Landsat 5. Revista Geociências, Rio Claro, v.28, n.2, p.153-164, 2009.

HEMAKUMARA, H.M.; CHANDRAPALA, L.; MOENE, A.F. Evapotranspiration fluxes over mixed vegetation areas measured from large aperture scintillometer. Agricultural Water Management, Amsterdam, v.58, p.109-122, 2003.

LATUF, M.O. Mudanças no uso do solo e comportamento hidrológico nas bacias do rio Preto e ribeirão Entre Ribeiros. 2007. 103 f. Dissertação (Mestrado em Engenharia Agrícola) Universidade Federal de Viçosa, Viçosa, 2007.

LIMA, E.P. Evapotranspiração de referência de Penman-Monteith, padrão FAO (1998), a partir de dados de temperaturas máxima e mínima de Minas Gerais. 2005. 67 f. Dissertação (Mestrado em Meteorologia Agrícola) - Universidade Federal de Viçosa, Viçosa, 2005.

LIMA, E.P.; SEDIYAMA, G.C.; GLERIANI, J.M.; SOARES, V.P.; DELGADO, R.C.; ANDRADE, R.G. Estimativa do balanço de radiação em áreas irrigadas utilizando imagem do Landsat 5 - TM. In: SIMPÓSIO BRASILEIRO DE SENSORIAMENTO REMOTO, 14., 2009, Natal. Anais... São José dos Campos: Instituto Nacional de Pesquisas Espaciais, 2009. 1 CD-ROM.

LIMA, E.P. Estimativa da evapotranspiração e do balanço hídrico a partir de imagens de satélite de duas sub-bacias do Paracatu. 2010. $161 \mathrm{f}$. Tese (Doutorado em Meteorologia Agrícola) Universidade Federal de Viçosa, Viçosa, 2010.

MENDONÇA, J.C. Estimativa da evapotranspiração regional utilizando imagens digitais orbitais na região Norte Fluminense, RJ. 2007. 145 f. Tese (Doutorado em Produção Vegetal) - Universidade Estadual do Norte Fluminense, Campos dos Goytacazes, 2007.

NICÁCIO, R.M. Evapotranspiração real e umidade do solo usando dados de sensores orbitais e a metodologia SEBAL na bacia do rio São Francisco. 2008. 320 f. Tese (Doutorado em Ciências em Engenharia Civil) - Universidade Federal do Rio de Janeiro, Rio de Janeiro, 2008.

OLIVEIRA, M.B.L.; SANTOS, A.J.B.; MANZI, A.O.; ALVALÁ, R.C.S.; CORREIA, M.F.; MOURA, M.S.B. Trocas de energia e fluxo de carbono entre a vegetação de caatinga e atmosfera no Nordeste brasileiro. Revista Brasileira de Meteorologia, São José dos Campos, v.21, n.3b, p.378-386, 2006.

PAIVA, C.M. Estimativa do balanço de energia e da temperatura da superfície via satélite NOAAAVHRR. 2005. 218 f. Tese (Doutorado em Ciências em Engenharia Civil) - Universidade Federal do Rio de Janeiro, Rio de Janeiro, 2005.

RODRIGUES, J.O.; ANDRADE, E.M.; TEIXEIRA, A.S.; SILVA, B.B. Sazonalidade de variáveis biofísicas em regiões semiáridas pelo emprego do sensoriamento remoto. Revista Engenharia Agrícola, Jaboticabal, v.29, n.3, p.452-465, jul./set. 2009. 
TASUMI, M.; ALLEN, R.G.; TREZZA, R. At-surface reflectance and albedo from satellite for operational calculation of Land surface energy balance. Journal of Hydrologic Engineering, Reston, v.13, n.2, p.51-63, 2008.

TEIXEIRA, A.H.C.; BASTIAANSSEN, W.G.M.; AHMAD, M.D.; BOS, M.G. Reviewing SEBAL input parameters for assessing evapotranspiration and water productivity for the Low-Middle São Francisco River basin, Brazil Part A: Calibration and validation. Agricultural and Forest Meteorology, Amsterdam, v.149, n.3-4, p. 462-476, 2009. 


\section{ERRATA: volume 32, número 6}

\section{p.1189 e 1190, onde se lê:}

"MENDONÇA (2007) estimated the instantaneous Rn for the Norte Fluminense region, State of Rio de Janeiro, using images from the MODIS sensor, and found values between 410 and $650 \mathrm{~W} \cdot \mathrm{m}^{-2}$ on August $29^{\text {th }}, 2005,500$ and $870 \mathrm{~W} \cdot \mathrm{m}^{-2}$ on November $16^{\text {th }}, 2005,480$ and $820 \mathrm{~W} \cdot \mathrm{m}^{-2}$ on February $5^{\text {th }}, 2006$, and 270 and $440 \mathrm{~W} \cdot \mathrm{m}^{-2}$ on June $15^{\text {th }}, 2006$. Although these two locations are in different latitudes, the Rn minimum of $419.13 \mathrm{~W} . \mathrm{m}^{-2}$, found in this study, was consistent with that one from MENDONÇA (2007) on August $29^{\text {th }}, 2005$, and the Rn maximum of $797.35 \mathrm{~W} . \mathrm{m}^{-2}$ found for the sub-basins of the Entre Ribeiros creek and Preto river, was compatible with the one from MENDONÇA (2007) on February $5^{\text {th }}, 2006 . "$

\section{Leia-se:}

Leia-se:

"MENDONÇA (2007) estimated the instantaneous Rn for the Norte Fluminense region, State of Rio de Janeiro, using products from the MODIS sensor, and found values between 411.76 and $646.64 \mathrm{~W} . \mathrm{m}^{-2}$ on August $29^{\text {th }}, 2005,499.06$ and $873.28 \mathrm{~W} \cdot \mathrm{m}^{-2}$ on November $16^{\text {th }}, 2005$, 482.40 and $818.32 \mathrm{~W} . \mathrm{m}^{-2}$ on February $5^{\text {th }}, 2006$, and 270.04 and $438.72 \mathrm{~W} . \mathrm{m}^{-2}$ on June $15^{\text {th }}$, 2006. Although these two locations are in different latitudes, the Rn minimum of $419.13 \mathrm{~W} . \mathrm{m}^{-}$ ${ }^{2}$, found in this study, was consistent with that one from MENDONÇA (2007) on August $29^{\text {th }}$, 2005, and the Rn maximum of $797.35 \mathrm{~W} . \mathrm{m}^{-2}$ found for the sub-basins of the Entre Ribeiros creek and Preto river, was compatible with the one from MENDONÇA (2007) on February $5^{\text {th }}, 2006 . "$ 